\title{
FAKTOR-FAKTOR YANG MEMENGARUHI PPh BADAN TERUTANG PADA PERUSAHAAN MANUFAKTUR DI BURSA EFEK INDONESIA
}

\author{
RIAN SUMARTA \\ AULIA ULMAH INTAN \\ Trisakti School of Management, Jl. Kyai Tapa No. 20, Grogol, Jakarta Barat, Indonesia \\ rian_sumarta@yahoo.com , auliaintan1998@gmail.com
}

\begin{abstract}
The purpose of this research is to obtain the factors that affect the corporate income tax. The independent variables of this research are capital structure (DER), profitability (ROA), operating cost, net sales, commercial expense, and luquidity ratio. The dependent variable in this research is corporate income tax. In this following research, the researchers used manufacture companies listed in Indonesia Stock Exchange from 2016-2018 which had 492 data from 164 companies. Based on criteria there are 177 data from 59 companies. The data was analyzed by using multiple regression analysis with IBM SPSS 19 version. The results of this research indicated that profitability (ROA), operating cost, and net sales have influence significant toward corporate income tax Minimizing operating costs in the company can affect the profitabil ity ratio and can increase company profits. Company profit comes from sales made by the company, profit is one of the tax objects, so that the amount of company profit can determine the amount of corporate income tax owed. However capital structure (DER), comercial expense, and liquidity ratio have no influence toward corporate income tax.
\end{abstract}

Keywords: Corporate income tax, der, roa, operating costs, liquidity ratio

Abstrak: Tujuan penelitian adalah untuk mengetahui faktorfaktor yang memengaruhi PPh badan terutang. Variabel independen penelitian ini adalah struktur modal (DER), profitabilitas (ROA), biaya operasional, penjualan bersih, beban komersial dan rasio likuiditas. Variabel dependen penelitian ini adalah Pph badan terutang. Penelitian ini menggunakan perusahaan manufaktur yang terdaftar di BEl periode 2016-2018 yang memiliki 492 data dari 164 perusahaan. Penelitian ini menggunakan metode purposive sampling. Berdasarkan kriteria terdapat 177 data dari 59 perusahaan. Data dianalisa menggunakan analisis regresi berganda dengan menggunakan IBM SPSS versi 19. Hasil dari penelitian ini menunjukkan bahwa profitabilitas (ROA), biaya operasional, dan penjualan bersih memiliki pengaruh signifikan terhadap Pph badan terutang. Meminimalisasi biaya operasional pada perusahaan dapat memengaruhi rasio profitabilitas dan dapat meningkatkan laba perusahaan. Laba perusahaan berasal dari penjualan yang dilakukan perusahaan, laba merupakan salah satu objek pajak, sehingga besarnya laba perusahaan dapat menjadi penentu jumlah pajak penghasilan badan terutang. Sedangkan struktur modal (DER), beban komersial, dan rasio likuiditas tidak memiliki pengaruh terhadap PPh badan terutang.

Kata kunci: PPh badan, der, roa, biaya operasional, rasio likuiditas. 


\section{PENDAHULUAN}

Pembangunan pada suatu negara membutuhkan biaya yang sangat besar. Pembangunan ini juga harus bersifat berkesinambungan demi memenuhi kesejahteraan setiap warga negara. Oleh karena itu, pemerintah membutuhkan suatu sumber pendanaan yang juga bersifat berkesinambungan dan terus-menerus. Dalam memenuhi kebutuhan pendanaan ini, pajak menjadi salah satu solusi utama bagi banyak negara, termasuk Indonesia. Sebagai negara yang sedang berkembang Indonesia membutuhkan lebih banyak dana pembangunan dibandingkan dengan negaranegara maju.

$\begin{array}{ccc}\text { Dalam } & \text { struktur } & \text { Anggaran } \\ \text { Pendapatan dan Belanja } & \text { Negara, }\end{array}$ pendapatan negara sekitar $80 \%$ didukung oleh penerimaan yang bersumber dari perpajakan. Akan tetapi, terkadang penerimaan perpajakan juga sering terkendala dengan tingkat kesadaran wajib pajak yang masih rendah dalam hal pemenuhan kewajiban perpajakan. Sebagian wajib pajak masih menganggap bahwa pembayaran pajak adalah suatu beban bukan kewajiban, karena pajak dikenakan kepada subjek pajak dimana didasari oleh undang-undang yang mana bersifat memaksa dan timbal balik nya tidak didapatkan secara langsung. Oleh karena itu, pemerintah melakukan berbagai cara yang efektif untuk membuat masyarakat menyadari betapa pentingnya membayar pajak.

Salah satu jenis pajak yang langsung dipungut oleh pemerintah pusat adalah pajak penghasilan. Pajak Penghasilan (PPh) adalah pajak yang dikenakan kepada orang pribadi atau badan atas penghasilan yang diterima atau diperoleh dalam suatu Tahun Pajak. Yang dimaksud dengan penghasilan adalah setiap tambahan kemampuan ekonomis yang diterima atau diperoleh Wajib Pajak baik yang berasal dari Indonesia maupun dari luar
Indonesia yang dapat dipakai untuk konsumsi atau untuk menambah kekayaan Wajib Pajak yang bersangkutan dengan nama dan dalam bentuk apapun. Dengan demikian maka penghasilan itu dapat berupa keuntungan usaha, gaji, honorarium, hadiah, dan lain sebagainya.

Berkaitan dengan peningkatan kesejahteraan masyarakat, salah satu upaya yang dilakukan pemerintah adalah melalui program pembangunan ekonomi dan investasi yang berfokus pada sektor industri. Tidak dipungkiri bahwa wajib pajak badan merupakan salah satu sumber penerimaan pajak yang cukup besar dan paling berpotensi untuk ditingkatkan di Indonesia, karena salah satu tujuan perusahaan adalah memaksimalkan kesejahteraan pemegang saham atau investor dengan cara memaksimalkan nilai perusahaan dengan cara memperoleh laba maksimum (Pohan, 2013, 3). Di sisi lain membayar pajak merupakan salah satu kewajiban perusahaan yang tidak dapat terhindarkan.

Seiring berkembangnya praktekpraktek bisnis baik nasional maupun multinasional, pajak penghasilan badan dapat diminimalisir dengan menggunakan berbagai teknik perencanaan pajak. Pajak bagi perusahaan merupakan suatu beban yang dapat mengurangi laba bersih sehingga dalam hal ini manajemen perusahaan selalu mengusahakan pembayaran pajak dengan jumlah seminimal mungkin.

Perusahaan yang memiliki proses bisnis dengan tingkat kompleksitas lebih tinggi akan dapat lebih mudah melakukan perencanaan pajak untuk meminimalisir pembayaran pajak. Salah satu contoh perusahaan yang memiliki tingkat kompleksitas proses bisnis adalah perusahaan manufaktur karena melibatkan suatu proses produksi yang mengolah suatu bahan baku menjadi barang setengah jadi atau barang jadi. Jenis perusahaan industri manufaktur masih mendominasi dari jumlah seluruh perusahaan yang ada di Indonesia. 
Banyak faktor yang dapat mempengaruhi jumlah pembayaran pajak penghasilan (PPh) dalam suatu perusahaan. Bustomi (2017) melakukan penelitian tentang pengaruh struktur modal dan profitabilitas terhadap beban Pajak Penghasilan (PPh) Badan pada perusahaan industri barang konsumsi yang terdaftar di Bursa Efek Indonesia (2013-2015). Variabel independen yang digunakan dalam penelitian adalah DER dan ROA, sedangkan variabel dependen adalah beban pajak penghasilan badan. Hasil penelitian menunjukkan bahwa secara parsial DER terdapat pengaruh terhadap beban Pajak Penghasilan badan.

Salamah et al. (2016) melakukan penelitian mengenai faktor yang mempengaruhi PPh Badan terutang. Variabel independen yang digunakan dalam penelitian ini adalah profitablitas dan biaya operasional memiliki pengaruh signifikan terhadap PPh badan terutang. Hasil penelitian Nindri (2015) menyatakan bagi perusahaan peningkatan beban komersial dapat membawa pengaruh positif yaitu penghematan Pajak Penghasilan terutang, akan tetapi bagi pemerintah (fiskus), jika perusahaan meningkat beban komersialnya tentu penerimaan dari sektor PPh Badan akan berkurang. Untuk itu peningkatan beban komersial yang terkait dengan perhitungan PPh terutang perlu mendapat pengawasan yang lebih karena dapat mengindikasikan adanya penghindaran pajak. Salah satu caranya dengan lebih memperhatikan isi peraturan pada pasal 6 ayat 1 UU PPh Tahun 2008 mengenai biayabiaya yang tidak boleh dikurangkan.

Penelitian yang dilakukan Yasinta (2017) yang menggunakan penjualan bersih dan beban komersial sebagai variabel independen, PPh Badan terutang sebagai variabel dependen mendapatkan hasil penelitian bahwa penjualan bersih dan beban komersial berpengaruh secara signifikan terhadap pph badan terutang. Selain itu, penelitian yang dilakukan Anam dan Zuardi
(2018) yang menggunakan rasio likuiditas, rasio solvabilitas dan biaya operasional sebagai variabel independen, PPh Badan terutang sebagai variabel dependen mendapatkan hasil penelitian bahwa rasio likuiditas, rasio solvabilitas dan biaya operasional berpengaruh positif dan signifikan terhadap PPh Badan terutang.

Penelitian ini merupakan pengembangan dari penelitian oleh Laksono (2019). Perbedaan penelitian ini dengan penelitian sebelumnya yaitu di tambahkan tiga variabel yang mempengaruhi pajak penghasilan badan terutang yaitu penjualan bersih, beban komersial dan rasio likuiditas. Adapun tujuan dari penelitian ini adalah untuk mengetahui pengaruh dari struktur modal, profitabilitas, biaya operasional, penjualan bersih, biaya komersial, dan rasio likuiditas terhadap pajak penghasilan badan.

\section{Teori Keagenan}

Teori keagenan menyatakan adanya hubungan kerja antara pihak yang memberi wewenang (prinsipal) yaitu investor dengan pihak yang menerima wewenang (agensi) yaitu manajer, dalam bentuk kontrak kerja sama yang disebut"nexus of contract". Perbedaan kepentingan tersebut memunculkan adanya konflik keagenan. Pada perusahaan besar, konflik keagenan terjadi pada hubungan antara (1) pemegang saham dan manajer, (2) manajer dan kreditur, (3) manajer, pemegang saham dan kreditur (Brigham dan Daves 2001).

Teori agensi mengasumsikan bahwa semua individu bertindak atas kepentingan mereka sendiri. Pemegang saham sebagai prinsipal diasumsikan hanya tertarik kepada hasil keuangan yang bertambah atau investasi mereka di dalam perusahaan. Para agen disumsikan menerima kepuasan berupa kompensasi keuangan dan syarat-syarat yang menyertai dalam hubungan tersebut. Karena perbedaan kepentingan ini masing-masing pihak berusaha memperbesar keuntungan 
bagi diri sendiri. Principal menginginkan pengembali-an yang sebesar-besarnya dan secepatnya atas investasi yang salah satunya dicerminkan dengan kenaikan porsi deviden dari tiap saham yang dimiliki. Agen menginginkan kepentingannya diakomodir dengan pemberian kompensasi/ bonus/ insentif/ yang memadai dan sebesarbesarnya atas kinerjanya. Principal menilai prestasi agen berdasarkan kemampuannya memperbesar laba untuk dialokasikan pada pembagian deviden. Hal ini menyebabkan munculnya perlakuan perpajakan yang agresif. Pihak agen akan selalu berusaha meminimalisir setiap potensi pembayaran pajak agar dapat meningkatkan laba bersih perusahaan.

\section{Pajak Penghasilan Badan}

Pajak Penghasilan (PPh) diatur dalam Undang-undang No. 7 tahun 1983 yang sudah mengalami empat kali amandemen, yaitu UU No. 7 tahun 1991, UU No. 10 tahun 1994, UU No. 17 tahun 2000 dan UU No. 36 tahun 2008. Dengan beberapa amandemen tersebut, dapat dikatakan bahwa UU PPh ini sudah mengikuti perkembangan sosial ekonomi masyarakat sebagai wujud pembangunan nasional bagi suatu bangsa, yang masih mengacu pada prinsip perpajakan secara universal.

Sesuai dengan UU No. 36 Tahun 2008, tarif PPh untuk WP Badan terdiri dari tiga tarif, yaitu tarif sesuai Pasal 17 ayat (1b), tarif sesuai Pasal 17 ayat (2b) UU PPh, dan tarif sesuai Pasal 31E. Pada Pasal 1 dalam Undang-undang Pajak Penghasilan (UU PPh). Pajak Penghasilan merupakan Pajak yang dikenakan terhadap subjek pajak atau atas penghasilan yang diterima atau diperoleh dalam satu tahun pajak. Sehingga, Pajak Penghasilan Badan (PPh Badan) merupakan pajak yang dikenakan atas penghasilan yang diterima atau diperoleh oleh suatu badan usaha seperti yang dimaksud dalam UU KUP.

PPh Tahunan Badan dihitung dengan mengalikan laba kena pajak dengan tarif PPh yang berlaku. Sedangkan, laba kena pajak adalah jumlah laba perusahaan setelah seluruh penghasilan yang diperoleh perusahaan dalam suatu tahun pajak (tidak termasuk penghasilan yang dikenakan PPh Final dan penghasilan yang bukan objek PPh) dikurangi dengan biaya mendapatkan, menagih dan memelihara penghasilan sesuai dengan pasal 6 UU PPh.

\section{Struktur Modal}

Penelitian sebelumnya yang dilakukan Ramadani (2010), Simamora dan Ryadi (2015) menunjukan hasil bahwa DER berpengaruh terhadap PPh Badan terutang. Struktur modal adalah perbandingan antara hutang dengan modal perusahaan sendiri. Jumlah hutang yang dimiliki perusahaan dapat mengurang jumlah pendapatan yang di terima perusahaan, oleh sebab itu laba kena pajak menjadi mengurang jumlahnya dan pada akhirnya besar pajak penghasilan yang dibayarkan berkurang.

$\mathrm{H}_{1}$ Terdapat pengaruh struktur modal dengan PPh Badan terutang.

\section{Profitabilitas}

Penelitian sebelumnya yang dilakukan Laksono (2019) menunjukan hasil bahwa profitabilitas berpengaruh terhadap PPh badan terutang. Profitabilitas merupakan suatu ukuran yang digunakan untuk melihat kemampuan perusahaan dalam menghasilkan pendapatan yang dapat diterima.

$\mathrm{H}_{2}$ Terdapat pengaruh profitabilitas dengan PPh Badan terutang.

\section{Biaya Operasional}

Penelitian sebelumnya yang dilakukan Salamah (2016) menunjukkan hasil bahwa biaya operasional berpengaruh terhadap PPh badan terutang. Biaya operasional adalah biaya yang berkaitan dengan operasi perusahaan diluar biaya 
produksi (Rudianto 2006). Biaya operasional merupakan suatu pengeluaran atau pengorbanan yang dilakukan oleh perusahaan untuk memperoleh manfaat.

$\mathrm{H}_{3}$ Terdapat pengaruh biaya operasional dengan PPh Badan terutang.

\section{Penjualan Bersih}

Penelitian sebelumnya yang dilakukan Yasinta (2017) menjunjukkan bahwa penjualan bersih berpengaruh terhadap PPh badan terutang. Penjualan merupakan kegiatan pelengkap atau suplemen dari pembelian untuk memungkinkan terjadinya transaksi (Assauri 2013, 23). Penjualan diakui sebagai revenue apabila produk telah terjual ke pelanggan dan masyarakat. Dengan demikian perusahaan berusaha untuk memperoleh laba yang besar bahkan berusaha untuk menaikkan jumlahnya itulah tujuan dari melakukan penjualan.

$\mathrm{H}_{4}$ Terdapat pengaruh penjualan bersih dengan PPh Badan terutang.

\section{Beban Komersial}

Penelitian sebelumnya yang dilakukan Yasinta (2017) menjunjukkan bahwa beban komersial berpengaruh terhadap PPh badan terutang. Beban pemasaran atau penjualan adalah keseluruhan biaya yang dikeluarkan perusahaan untuk mendistribusikan barang produksi hingga sampai kepada konsumen (Rudianto 2006, 209). Jika perusahaan memproduksi produk terbaru dan ingin diketahui oleh masyarakat luas, maka perusahaan akan melakukan promosi atau pemasaran kepada produk tersebut.

$\mathrm{H}_{5}$ Terdapat pengaruh beban komersial dengan PPh Badan terutang

\section{Rasio Likuiditas}

Penelitian sebelumnya yang dilakukan Puspitasari dan Amah (2019) menunjukkan bahwa rasio likuiditas berpengaruh terhadap PPh badan terutang.
Rasio likuiditas adalah rasio yang digunakan untuk mengukur tingkat kemampuan perusahaan dalam memenuhi kewajiban jangka pendeknya yang akan jatuh tempo (Hery 2017, 284). Rasio likuiditas merupakan rasio yang dapat melihat kemampuan perusahaan dalam memenuhi kewajiban atau membayar hutang jangka pendek perusahaan.

$\mathrm{H}_{6}$ Terdapat pengaruh rasio likuiditas dengan PPh Badan terutang.

\section{METODE PENELITIAN}

Dalam penelitian ini sampel yang digunakan adalah perusahaan yang bergerak di sektor manufaktur yang tercatat di Bursa Efek Indonesia (BEI) periode 2016-2018. Teknik yang digunakan untuk mengambil sampel ini adalah purposive sampling. Sampel dalam penelitian ini terdapat 59 perusahaan yang lolos kriteria dari 177 data sampel perusahaan.

PPh adalah pajak yang dipungut terhadap penghasilan yang berasal dari luar maupun dalam suatu perusahaan yang diperoleh dalam tahun pajak atau dapat dikenakan pajak untuk penghasilan dalam bagian tahun pajak. Menurut pasal 17 UU PPh, cara menghitung PPh Badan yaitu mengalikan penghasilan kena pajak dengan tariff PPh badan. Dapat dirumuskan sebagai berikut:

PPh Badan = Penghasilan kena pajak $\mathrm{x}$ tarif pajak penghasilan

Struktur Modal merupakan pembanding antara hutang dan modal sendiri maupun asing. Modal asing yang dimaksud yaitu hutang jangka panjang maupun hutang jangka pendek. Debt to Equity Ratio (DER) merupakan rasio yang membandingkan antara total hutang perusahaan dengan modal perusahaan sendiri. Struktur modal dapat dirumuskan sebagai berikut: 
DER $=\frac{\text { Hutang }}{\text { Modal }}$

Dalam penelitian ini, peneliti dalam mengukur profitabilitas menggunakan rasio Return On Asset (ROA). ROA dapat diukur dengan membagi laba sebelum pajak dengan total aset milik perusahaan pada periode tertentu (Rodriguez dan Arias 2012) dalam Ardyansah dan Zulaikha (2014). Dengan demikian, ROA dapat dirumuskan sebagai berikut:

$\mathrm{ROA}=\frac{\text { Laba sebelum pajak }}{\text { Total aset }}$

Biaya operasional merupakan biaya yang harus dikeluarkan oleh perusahaan, biaya operasional tidak ada hubungan dengan produk, tetapi berhubungan dengan kegiatan operasional perusahaan. Indikator yang digunakan untuk mengukur biaya operasional menurut (Rudianto 2006, 23) dapat dirumuskan sebagai berikut:

Biaya operasional $=$ Biaya Penjualan + Biaya Umum dan Administrasi

Penghasilan yang didapat perusahaan terjadi karena adanya penjualan dari aktivitas perusahaan. Penjualan bersih adalah jumlah yang diterima dari penjualan setelah dikurangi dengan nilai barang yang dikembalikan dan cadangan (Rahardjo 2005, 48). Dapat dirumuskan sebagai berikut:

$\begin{aligned} \text { Penjualan Bersih }= & \text { Penjualan - } \\ & \text { Retur } \\ & \text { Penjualan - } \\ & \text { Potongan } \\ & \text { Penjualan }\end{aligned}$

\footnotetext{
Beban komersial merupakan besarnya jumlah yang dikeluarkan perusahaan yang dapat diakui sebagai biaya atau beban, termasuk didalamnya yaitu beban komersial, beban pokok penjualan,
}

beban administratif, dan beban angkut. Beban komersial dapat dirumuskan sebagai berikut:

Beban Komersial = BPP (Beban Pokok Penjualan) + beban usaha + beban lain-lain

Rasio likuiditas merupakan rasio yang mampu menilai sejauh mana perusahaan dapat memenuhi kewajiban untuk membayar hutang jangka pendek perusahaan tersebut. Jika perusahaan mempunyai kemampuan dalam memenuhi kewajibannya berarti perusahaan tersebut likuid, sedangkan jika perusahaan tidak mempunyai kemampuan untuk memenuhi kewajibannya berarti perusahaan tersebut ilikuid. Quick Ratio (rasio cepat) merupakan rasio likuiditas yang dapat digunakan oleh perusahaan untuk melihat kemampuan perusahaan.

Rasio cepat adalah rasio yang dapat menunjukkan apakah perusahaan mampu untuk memenuhi kewajiban atau hutang lancar dengan aktiva lancarnya.

Quick Ratio $=\frac{\text { Aktiva Lancar }- \text { Persediaan }}{\text { Hutang Lancar }}$

\section{HASIL PENELITIAN}

Koefisien determinasi dari perhitungan tabel 2 di atas diperoleh angka adjusted $\mathrm{R}^{2}$ sebesar 0,971 atau setara dengan $97,1 \%$. Hal ini menunjukkan bahwa variabel PPh Badan terutang dipengaruhi $97,1 \%$ oleh variabel independen dalam penelitian ini, sedangkan sisanya sebesar 2,9\% dipengaruhi oleh faktor lain yang tidak dimasukkan dalam model regresi. Hasil analisis uji $\mathrm{F}$ yang ditunjukkan pada tabel 3 memiliki nilai sig. 0,000 yang berarti nilai sig. $<0,05$ sehingga dapat disimpulkan bahwa model regresi yang digunakan adalah fit atau layak sehingga data baik digunakan dalam penelitian. Hasil pengukuran uji t dapat dilihat pada tabel sebagai berikut: 
Tabel 1 Analisis Regresi Linier Berganda

\begin{tabular}{llll}
\hline \multicolumn{1}{c}{ Variabel } & B & Sig. & \multicolumn{1}{c}{ Keterangan } \\
\hline Constant & 4,430 & 0.004 & \\
Struktur Modal $\left(X_{1}\right)$ & $-1,233$ & 0.422 & $\mathrm{Ha}_{1}$ tidak diterima \\
Profitabilitas $\left(\mathrm{X}_{2}\right)$ & 4,188 & 0.000 & $\mathrm{Ha}_{2}$ diterima \\
Biaya Operasional $\left(X_{3}\right)$ & $-0,006$ & 0.311 & $\mathrm{Ha}_{3}$ tidak diterima \\
Penjualan Bersih $\left(X_{4}\right)$ & 0,014 & 0.000 & $\mathrm{Ha}_{4}$ diterima \\
Beban Komersial $\left(X_{5}\right)$ & $-0,012$ & 0.000 & $\mathrm{Ha}_{5}$ diterima \\
Rasio Likuiditas $\left(X_{6}\right)$ & $-1,666$ & 0.632 & $\mathrm{Ha}_{6}$ tidak diterima \\
\hline
\end{tabular}

Sumber: Data yang diolah

Nilai sig. pada struktur modal $\left(\mathrm{X}_{1}\right)$ sebesar 0.442 lebih besar dari alpha 0,05 , sehingga dapat disimpulkan bahwa $\mathrm{Ha}_{1}$ tidak diterima. Hal ini menunjukkan bahwa variabel struktur modal tidak berpengaruh terhadap PPh Badan terutang. Hasil penelitian ini menolak hipotesis bahwa terdapat pengaruh struktur modal terhadap PPh Badan terutang. Hasil penelitian ini tidak konsisten dengan hasil penelitian Salamah et al. (2016), Laksono (2019) dan Vindasari (2019) dimana struktur modal (DER) berpengaruh positif terhadap PPh Badan terutang.

Nilai sig. pada profitabilitas $\left(\mathrm{X}_{2}\right)$ 0.000 lebih kecil dari alpha 0,05 , dan memiliki arah positif sehingga dapat disimpulkan bahwa $\mathrm{Ha}_{2}$ diterima. Hal ini menunjukkan bahwa variabel profitabilitas berpengaruh terhadap PPh Badan terutang terutang. Hasil penelitian ini mendukung hipotesis bahwa terdapat pengaruh positif antara profitabilitas yang diukur dengan ROA terhadap PPh Badan. Hal ini menunjukkan bahwa semakin tinggi nilai profitabilitas (ROA) perusahaan, maka semakin besar PPh Badan terutang yang dibayarkan karena semakin tinggi nilai ROA menunjukkan bahwa perusahaan mempunyai kemampuan untuk memperoleh laba yang tinggi. Hasil penelitian ini konsisten dengan penelitian Yovyta (2017), Laksono (2019) dan Vindasari (2019) dimana profitabilitas (ROA) berpengaruh positif terhadap PPh Badan terutang.

Nilai sig. pada biaya operasional $\left(\mathrm{X}_{3}\right)$ sebesar 0.31 lebih besar dari alpha 0,05, sehingga dapat disimpulkan bahwa $\mathrm{Ha}_{3}$ tidak diterima. Hal ini menunjukkan bahwa variabel biaya operasional tidak berpengaruh terhadap PPh Badan terutang. Hasil penelitian ini menolak hipotesis bahwa terdapat pengaruh antara biaya operasional terhadap PPh Badan terutang. Hasil penelitian ini tidak konsisten dengan penelitian Salamah et al. (2016) dan Laksono (2019) serta Vindasari (2019) dimana biaya operasional berpengaruh positif terhadap PPh Badan terutang.

Nilai sig. pada penjualan bersih $\left(\mathrm{X}_{4}\right)$ sebesar 0,000 lebih kecil dari alpha 0,05, sehingga dapat disimpulkan bahwa $\mathrm{Ha}_{4}$ diterima. Hal ini menunjukkan bahwa variabel penjualan bersih berpengaruh terhadap PPh Badan terutang. Hasil penelitian ini mendukung hipotesis bahwa terdapat pengaruh positif antara penjualan bersih terhadap PPh Badan. Hal ini menunjukkan bahwa semakin tinggi nilai penjualan bersih maka semakin besar nilai PPh Badan, hal ini dikarenakan semakin tinggi nilai penjualan bersih maka jumlah penghasilan kena pajak akan semakin tinggi sehingga menyebabkan PPh Badan terutang semakin tinggi. Hasil penelitian ini konsisten dengan penelitian Ramadhani (2010), Yasinta (2017), Nengsih (2018) yang menyatakan bahwa penjualan bersih berpengaruh positif terhadap PPh Badan terutang.

Nilai sig. pada beban komersial $\left(X_{5}\right)$ 
sebesar 0,000 lebih kecil dari alpha 0,05, sehingga dapat disimpulkan bahwa $\mathrm{Ha}_{5}$ diterima. Hal ini menunjukkan bahwa variabel beban komersial berpengaruh negatif terhadap PPh Badan terutang. Hasil penelitian ini mendukung hipotesis bahwa terdapat pengaruh antara beban komersial terhadap PPh Badan. Hal ini menunjukkan bahwa semakin tinggi nilai beban komersial perusahaan, maka semakin rendah PPh Badan yang dibayarkan, karena jumlah laba akan semakin rendah dan perhitungan nilai PPh Badan yang dibayarkan juga akan semakin rendah, begitu juga sebaliknya. Peningkatan jumlah beban komersial perusahaan yang terkait dengan PPh Badan perlu mendapat pengawasan karena dapat menunjukkan adanya penghindaran pajak. Hasil penelitian ini konsisten dengan penelitian Kusumadewi (2008), Ramadhani (2010), Yasinta (2017) dan Nengsih (2018) dimana beban komersial berpengaruh positif terhadap PPh Badan terutang.

Nilai sig. pada Rasio Likuiditas $\left(\mathrm{X}_{6}\right)$ sebesar 0,632 lebih besar dari alpha 0,05, sehingga dapat disimpulkan bahwa $\mathrm{Ha}_{6}$ tidak diterima. Hal ini menunjukkan bahwa variabel Rasio Likuiditas tidak berpengaruh terhadap PPh Badan terutang. Hasil penelitian ini menolak hipotesis bahwa terdapat pengaruh antara Rasio Likuiditas terhadap PPh Badan. Hasil penelitian ini tidak konsisten dengan penelitian Zuardi dan Anam dan Zuardi (2018), dimana Rasio Likuiditas berpengaruh positif terhadap PPh Badan terutang.

\section{PENUTUP}

Struktur modal tidak berpengaruh terhadap PPh Badan terutang. Struktur modal yang diukur dengan Debt to Equity Ratio (DER) pada masing-masing perusahaan sampel menunjuk-kan bahwa perusahaan mengelola jumlah pinjaman dengan baik, hal ini dikarenakan terdapat peraturan perpajakan yang membatasi rasio
DER maksimum hanya sebesar $4: 1$. Sehingga dalam hal ini, tingkat beban bunga yang dapat dikurangkan yang dapat dikurangkan dalam menghitung laba kena pajak juga menjadi sangat terbatas sehingga tidak ada pengaruh antara jumlah pembayaran PPh Badan antara perusahaan dengan tingkat hutang yang sangat tinggi dengan tingkat yang sangat rendah.

Profitabilitas berpengaruh positif terhadap PPh Badan terutang. Rasio Profitabilitas menunjukkan kemampu-an untuk memperoleh laba. Semakin tinggi tingkat profitabilitas maka tentunya akan semakin besar laba yang diperoleh. Hal ini akan berbanding lurus dengan PPh Badan yang terutang, semakin besar laba maka akan semakin besar PPh Badan terutang.

Biaya operasional tidak berpengaruh terhadap PPh Badan terutang. Biaya operasional merupakan pengeluaran uang untuk melaksanakan kegiatan pokok, yaitu berupa biaya penjualan dan administrasi untuk memperoleh pendapatan, tidak termasuk pengeluaran yang telah diperhitungkan dalam harga pokok penjualan.

Perusahaan yang mampu mengelola pendapatan maka kegiatan perusahaan dapat berjalan dengan efektif dan lancar sehingga perusahaan juga wajib untuk dapat mampu menilai seberapa besar beban operasional yang harus dikeluarkan agar perusahaan memperoleh laba sesuai yang direncanakan.

Penjualan bersih berpengaruh positif terhadap PPh Badan terutang. Semakin tinggi tingkat penjualan bersih perusahaan tentunya akan semakin tinggi pula laba yang diperoleh perusahaan. Hal ini tentunya akan berbanding lurus dengan PPh Badan terutang. Semakin tinggi laba maka akan semakin tinggi jumlah PPh yang harus dibayar.

Beban komersial berpengaruh negatif terhadap PPh Badan terutang. Beban 
komersial merupakan komponen pengurang penghasilan. Semakin tinggi beban komersial maka akan semakin rendah tingkat laba yang diperoleh perusahaan sehingga PPh Badan terutang juga menjadi rendah, begitu juga sebaliknya.

Rasio likuiditas tidak berpengaruh terhadap PPh Badan terutang. Rasio likuiditas merupakan rasio yang mampu menilai sejauh mana perusahaan dapat memenuhi kewajiban untuk membayar hutang jangka pendek perusahaan tersebut. Hal ini tidak berkaitan langsung dengan tingkat penghasilan perusahaan, akan tetapi hanya berkaitan dengan arus uang.

Keterbatasan penelitian ini adalah (1) data perusahaan yang digunakan sebagai obyek penelitian hanya 3 tahun yaitu periode 2016-2018, (2) data perusahaan yang digunakan sebagai obyek penelitian hanya dari sektor perusahaan manufaktur, (3) penelitian ini hanya menggunakan 6 variabel independen yaitu struktur modal, profitabilitas, biaya operasional, penjualan bersih, beban komersial dan rasio likuiditas.

\section{REFERENCES:}

Anam, Chairul dan Lustyna Reinsa Zuardi. 2018. Analisis Rasio Likuiditas, Rasio Solvabilitas, Dan Biaya Operasional Terhadap Pajak Penghasilan Badan Terutang (Sektor Pertambangan Di BEI Tahun 2011-2016). Margin Eco, 2(1), 43-68.

Ardyansah, Danis dan Zulaikha. 2014. Pengaruh Size, Leverage, Profitability, Capital Intensity Ratio Dan Komisaris Independen Terhadap Effective Tax Rate (ETR). Diponegoro Journal of Accounting, 3(2), 371-379.

Assauri, Sofjan. 2013. Manajemen Pemasaran. Jakarta: PT Raja Grafindo Persada

Brigham, E.F. dan Daves, P. R. 2001. Intermediate Financial Management, 7th edition. Orlando: The Dryden Press.

Bustomi, Cindy Chalik. 2017. Pengaruh Struktur Modal Dan Profitabilitas Terhadap Beban Pajak Penghasilan Badan (Survei pada Sektor Industri Barang Konsumsi yang Terdaftar di BEI Periode Tahun 2013 - 2015) ". Undergraduate thesis, Universitas Kristen Maranatha.

Hery. 2017. Teori Akuntansi Pendekatan Konsep dan Analisis. Jakarta: PT Grasindo.

Nengsih, Silvia. 2018. Pengaruh Struktur Modal, Penjualan Bersih Dan Manajemen Laba Terhadap Beban Pajak Penghasilan Badan Terutang Pada Perusahaan Manufaktur Di Bursa Efek Indonesia. Sarjana thesis yang tidak dipublikasi, Universitas Putra Indonesia YPTK Padang. Nindri Putri. 2015. Pengaruh Modal Sendiri dan Utang Jangka Panjang Terhadap Pajak Penghasilan Badan Terutang Pada Perusahaan Yang Terdaftar Di Bursa Efek Indonesia. Skripsi yang tidak dipublikasikan. Universitas Pakuan. Bogor.

Laksono, Roni Dwi. 2019. Pengaruh Struktur Modal (Leverage, Debt Equity Ratio, Long Term Debt To Asset Ratio), Profitabilitas, \& Biaya Operasional Terhadap Pajak Penghasilan Badan Terhutang Pada Perusahaan Manufaktur Yang Terdaftar Di BEI Periode Tahun 2015 - 2017. Tirtayasa Ekonomika, 14(1).

Pohan, Chairil Anwar. 2013. Manajemen Perpajakan. Gramedia Pustaka Utama. Jakarta.

Puspitasari, Dyah Ayu Linda dan Nik Amah. 2019. Pengaruh Profitabilitas Likuiditas dan Biaya Operasional Terhadap Pajak Penghasilan Badan (Studi Pada Perusahaan Manufaktur Sub Sektor Industri Barang Konsumsi Yang Terdaftar di Bursa Efek Indonesia Periode Tahun 2015-2017). Seminar Inovasi Manajemen, Bisnis Dan Akuntansi I (SIMBA), Fakultas Ekonomi dan Bisnis UNIPMA. 
Rahardjo, Budi. 2005. Laporan Keuangan Perusahaan, Seri Membaca, Memahami, Menganalisis Edisi Cetakan Pertama. Gajah Mada, Yogyakarta.

Ramadhani, Endah Nilam. 2010. Analisis Pengaruh Struktur Modal Terhadap PPh Badan Terutang Pada Perusahaan Yang Terdaftar di BEl Periode 2005-2009. Skripsi yang tidak dipublikasi, Universitas Islam Negeri Syarif Hidayatullah.

Rudianto. 2006. Akuntansi Manajemen: Informasi untuk Pengambilan Keputusan Strategis. Yogyakarta: Grasindo.

Salamah, Asri Anggun, Maria Goretti Wi Endang Nirowati Pamungkas dan Kumara Yogi. 2016. Pengaruh Profitabilitas dan Biaya Operasional Terhadap Pajak Penghasilan Badan (Studi Pada Perusahaan Manufaktur Yang Terdaftar di Bursa Efek Indonesia Periode 2012-2014). Jurnal Perpajakan (JEJAK), 9(1).

Simamora, Patar dan Muhamad Ressa Mahardika Ryadi. 2015. Pengaruh Struktur Modal Terhadap Pph Badan Terutang Pada Perusahaan Manufaktur Sektor Industri Semen Yang Terdaftar Di BEI Periode 2010-2013. Jurnal IImiah Akuntansi Fakultas Ekonomi (JIAFE), 1(2), 21-31. Undang-Undang Nomor 36 Tahun 2008 tentang Pajak Penghasilan.

Vindasari, Renanda. 2019. Pengaruh Debt To Equity Ratio, Return On Asset, dan Biaya Operasional Terhadap Pajak Penghasilanbadan Terutang (Studi Kasus Pada Perusahaan Manufaktur Sektor Industri Barang Konsumsi Di Bursa Efek Indonesia Periode 2015-2017). Jurnal Analisa Akuntansi dan Perpajakan, 3(2), 90-97.

Yasinta, Adyta Nur. 2017. Pengaruh Penjualan Bersih dan Beban Komersial Terhadap Pajak Penghasilan Badan Terutang (Studi Kasus Pada Perusahaan Manufaktur Yang Terdapat Di BEI). Jurnal Jurusan Akuntansi Fakultas Ekonomi Universitas Pakuan.

Yovyta, Neli Gustin. 2017. Pengaruh Struktur Modal Dan Profitabilitas Terhadap Beban Pajak Penghasilan Badan Terutang Pada Perusahaan Jasa Yang Listing di BEI Pada Tahun 20132015. Diploma thesis yang tidak dipublikasi, Universitas Andalas. 